嶼下障害を伴った巨大なロ底類表皮京胞の 1 例

\author{
西嶋 克已・石田 利広・長畠黢一郎 \\ 前田健一郎・和気 和也・元井 信*
}

\title{
A case of large epidermoid cyst of the floor of the mouth following difficult in swallowing.
}

\author{
Katsumi Nishijma - Toshihiro Ishida - Shunichiro Nagahata \\ Kenichiro MAEDA - Kazuya WAKE Makoto Motoi*
}

緒

言

類皮蹗胞あるいは類表皮哥胞は外胚葉の嵌入により生 ずる裂胞で，口腔領域に発生することは比較的少ないと いわれている1)。その蹗胞壁が皮甬様の組織, 寸なわち，

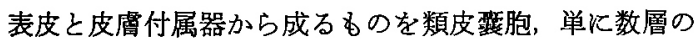

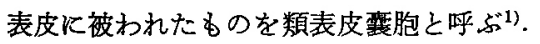

今回我々は，口底部に発生した巨大な類表皮䀺胞で燕 下障害を伴った桸有な症例を経験したので報告する。

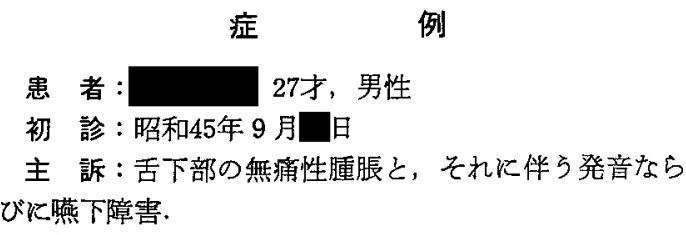

\section{家族歴，既往歴：特記事項な乙}

現病歴：約 6 年前より舌下部中央にクルミ大無痛性廆 脹を認めるも放置. その後, 腫脤は徐々に增大し, 約 1 年 前には舌が挙上され，言語障害ならびに燕下障害を招く

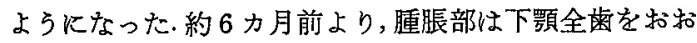
い，咀喂時に腯脹部辺緑を咬むようになったため来院.

現症

全身所見：体格，栄盖は良好で，特記事項なし。

局所所見

口腔外所見：括とがい下部より両側顎下部汇かけ腫脹 を認めた·左䫇下リンパ節に小豆大 2 個, 右額下リンパ節 には小指頭大 1 個と小豆大 1 個を触知したが，リンパ節

岡山大学医学部口腔外科学教室 (主任：西嶋克巳教授)

*同山大学医学部第 2 病理学教室（主任：小川勝士教授）

Department of Oral Surgery, Okayama University Medical School (Chief : Prof. Katsumi Nishijima)

2nd. Department of Pathology, Okayama University Medical School* (Chief : Prof. Katsuo Ogawa)

受付 : 昭和50年 12 月 29 日

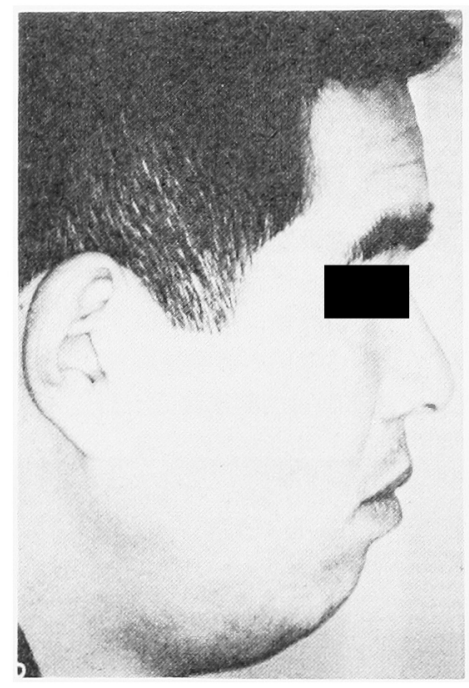

写真 1 術前側貌

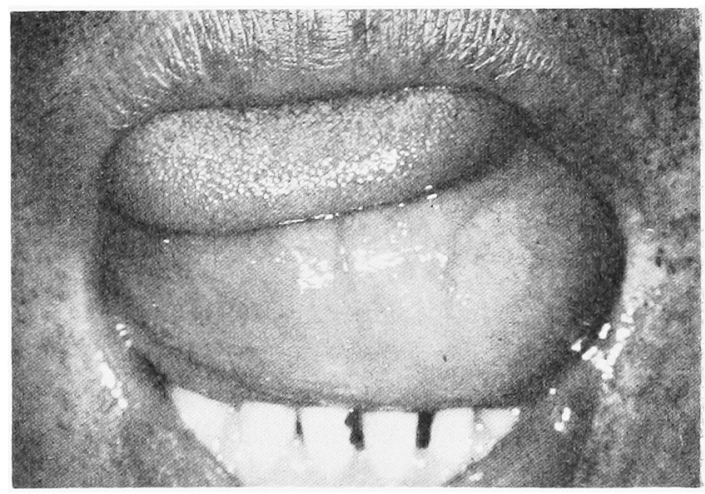

写真 2 口腔内 
は可動性, 弾性軟で、王痛は認められなかった（写真1）.

口腔内所見 : 舌下部に小児手拳大の腫脹を認め，その 腫脹により舌は挙上され，後方に押しやられていた．藮 胞表面に霜による压痕が認められたが, 表面粘膜色は正 常で，触診により粘膜と露胞との瘁着は認められなかっ

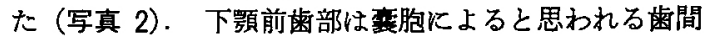
離開を認めたが，咬合状態は正常であったまた腫脹の ため, 舌運動, 䵒下および発音障害を認めた.

臨床検査成綪：血液検查結果は表 1 亿示したと和りで あり，血清蛋白検查，尿検査抢よび他の内科的検查には 異常を認めなかった（表 1).

表 1 血液検查

\begin{tabular}{|c|c|}
\hline 赤血球数 & $581 \times 10^{4} / \mathrm{mm}^{3}$ \\
\hline 血色索量 & $16.4 \mathrm{~g} / \mathrm{dl}$ \\
\hline 色素指数 & 0.88 \\
\hline $\begin{array}{l}\text { 白 血 球 数 } \\
\text { 白 血 球 像 }\end{array}$ & 10500 \\
\hline 抺中球 $\{$ 杆状核 & $5 \%$ \\
\hline 好 中域 $\{$ 分葉核 & $56 \%$ \\
\hline 好 酸 球 & $1 \%$ \\
\hline 好塩基球 & $2 \%$ \\
\hline 単球 & $5 \%$ \\
\hline リンパ球 & $31 \%$ \\
\hline 栓 数 & $18.6 \times 10^{4}$ \\
\hline 出血 時間 & 3 分30秒 \\
\hline ヘマトクリット & $44 \%$ \\
\hline
\end{tabular}

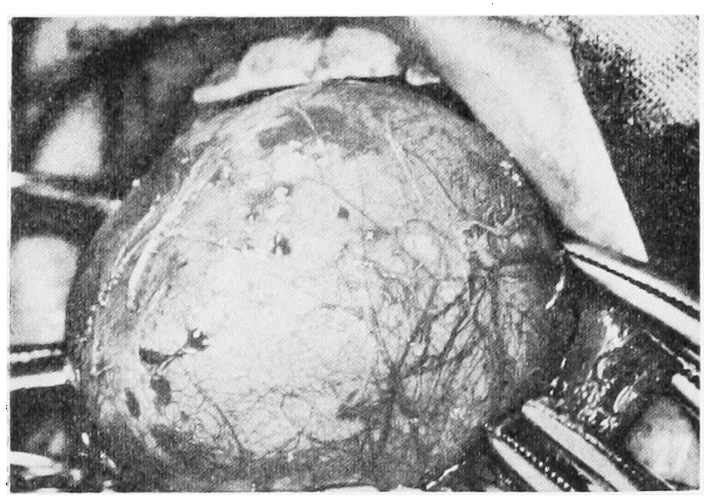

写真 3 尧胞摘出中

臨床診断：類皮軎胞

処置およひ経過：G-O-F 全身麻醉のもとに，襄胞正 中部の口腔粘膜に緃切開を加光，要胞壁を破らぬ上らに 注意して，一塊として摘出した（写真 3）. 西胞は，舌 下部より左右顎二腹管の間にみられ，周因組織を圧迫し ていた，術後の経過は良好で，術前にみられた舌運動， 鞇下および発音障害も徐々に改善され，12日後退院し， 現在まで再発はみられない。

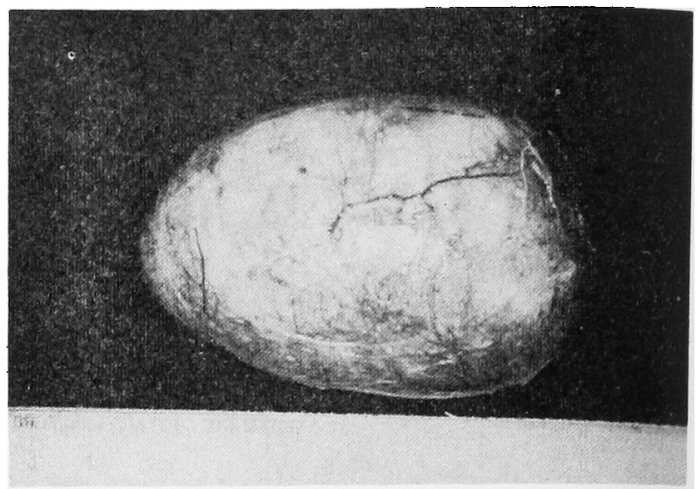

写真 4 摘出物

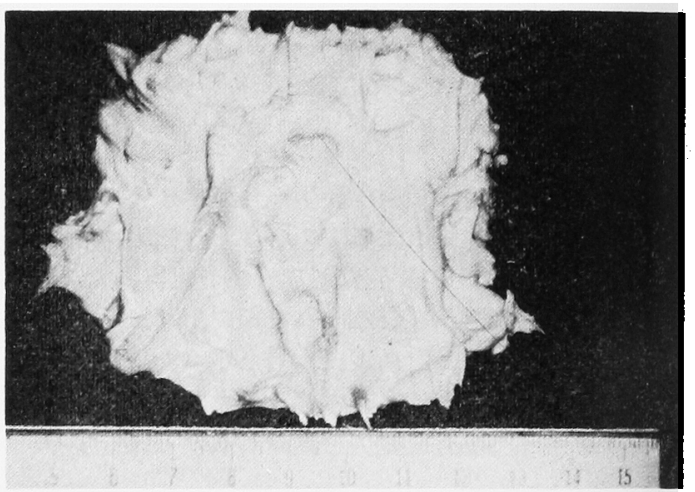

写真 5 摘出物割面

摘出物所見：大きさは，小児手拳大 $(8.0 \times 5.3 \times 5.3) \mathrm{cm}$ の卵円形を呈し，血管に富んだ被膜でおおわれていた。 内容物は，軟泥状，带黄灰白色，ハター状物が充淦して いた（写真 4，5）。

組蟣学的所見：变胞壁は，部位により多少その巾に広 狭の差はあったが，ほぼ一様に数層の重層扁平上皮から 成り，その基底部には紡鉼形の基底細胞が並び，亳胞内 面には層板状の角化物質を有していた，粘膜下結合組絊 は,こくく軽度のリンパ球浸潤が散在性に認められたが， 巨細胞を伴ら肉芽性炎症は認められなかった。しかる京 胞壁には皮層付属組織を欠如していた（写真 6).

以上の所見から, 病理組織学的に類表皮蓄胞と診断さ れた.

\section{粉括ならびに考察}

類表皮蕒胞の成り立ちについては，一般に先天的なる の,すなわち，胎生期に拈ける外肧葉の迷入によって生 ずると考えられており2，口暌領域では主に口底部にみ られる ${ }^{1)}$. Bergmann ${ }^{3}$ によれば口底の大部分は，而側の 第 1 ，第 2 鰓弓の正中疻合部に上皮が嵌入して生ずると されている。しかし，その嵌入する部位については未枕 


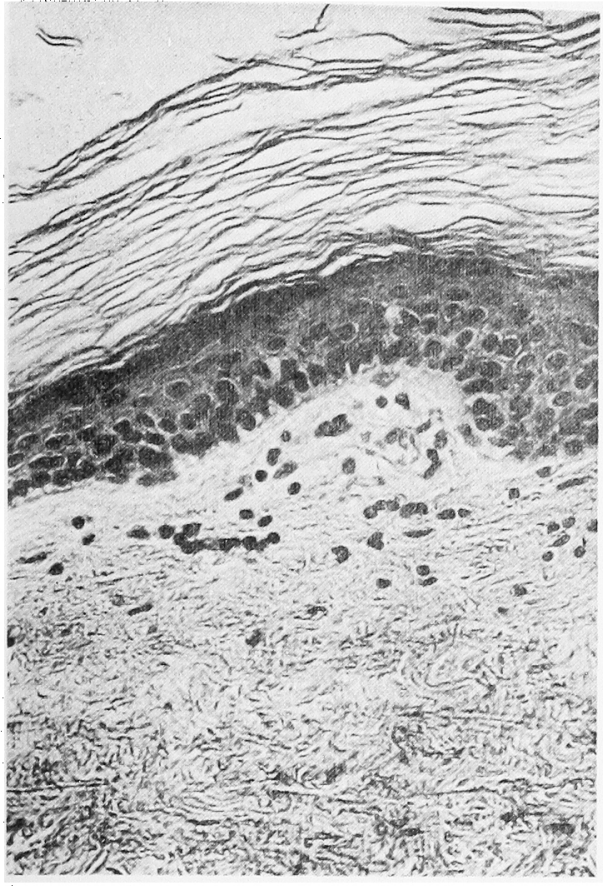

写真 6 病理組織像 H. E. 染色

明らかでなく種々の説があるが，いずれる胎生学上か らの推論にすぎず，確実な証明は团難である。すた， Anderson ${ }^{4)}$ おび Ackerman ${ }^{5)}$ は，外傷または炎症に よって，外胚葉が内肧葉内に分離残存するために生ずる ことがあると述ぺている。

病理組織学的には，Meyer ${ }^{2)}$ の分類が一般に適用され て挌り，Thoma \& Goldman'6) もこれを支持している. すなわら，第 I 型から第而型に分類し，第I 型の類表皮

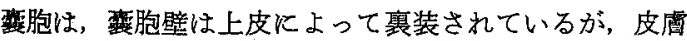

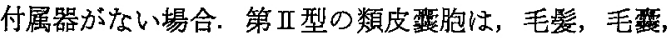
皮脂腺，汗腺などの皮㲊付属器が包含されている場合.

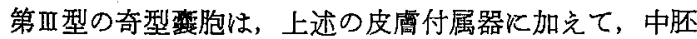
莱組織たとえば骨，筋，呼吸器系むるいは消化器系組織 などが包含されている場合. 以上のように分類している

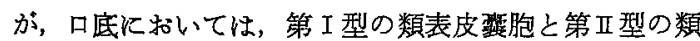
皮葆胞に属するるのが大半であると述べている。また Török ${ }^{8)}$ は，外胚葉の迷入時期によって差異が生ずると し，早期に迷入すれば類皮要胞，晚期に迷入すれば類表 皮露胞を生ずると述べている。

類表皮琵胞ヶよび類皮胞の頻度について，高橋，大

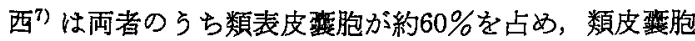
や中間型よりるやや多がたた述べている.

性别発現率について, New \& Erich" ${ }^{9}$ は103例中, 男 $51 \%$ ，女49\%，また高橋，大西7) 473 例中，男 $43.7 \%$ ， 女56. 3\%，三村 ${ }^{10}$ 恃40例中，男 $42.5 \% ， 女 57.5 \%$ と記し て淤り，注とんど性差はないようである。
年齢別発現率については，先天性荲胞であるから，発 生学的には胎生期に発生するべきすの゙ある.しかし， 16才〜35才位に整胞の発育するるのが多い们，それにつ いて Meyer $^{2}$ は，20才前後に抽いて表皮組織の活動か 著しくなり，毛贸の発育や，汗腺，皮脂腺の活動子盛ん になるためであるうと述べている，

発生部位火関しては，Bergmann ${ }^{3}$ 《露胞が顠舌骨筋

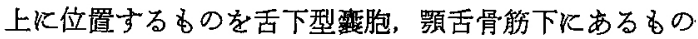
を，牤とがい下型变胞に分類し，萩崎 ${ }^{122}$ はこれに舌下よ り顎舌骨能を超えて技とがい下にわたる巨大なるのを， 舌和とがい下型要胞として加光ている，本症例は，舌お とがい下型整胞ですった。

酸胞の大きさについては, New \& Erich") は頭頸部 領域に括いて，103例中， $4 \mathrm{~cm}$ から $10 \mathrm{~cm} の$ 種々の大き さが存在し，大きいものは日底部に存在すると報告して いる，本邦症例中では，萩崎 ${ }^{12} の 12.0 \times 8.0 \mathrm{~cm}$ が最大 とされ，次いで森 ${ }^{18} の 10.0 \times 8.0 \mathrm{~cm}$ が報告されている. その他巨大な百のとして野村ら ${ }^{14)}$ の $8.5 \times 8.0 \mathrm{~cm}$, 新森, 篠原 ${ }^{15)} 6.1 \times 4.3 \mathrm{~cm}$, 長谷川沾 ${ }^{16)}$ の $4.9 \times 4.4 \mathrm{~cm}$ 占 報告されている，われわれの症例は $8.5 \times 5.3 \mathrm{~cm}$ であり，

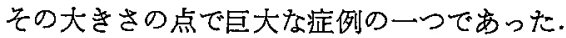

一般に臨床的症状は, 襄胞の解剖学的位置と大きさに 重要な関係があり，おとがい下型霆胞では機能障害は著 明ではないが，舌下型执よび舌抗とがい下型では，大き くなると哭下困難，発音障害，崡列弓拡大，歯牙前方傾 斜，下䫇前雪部の歯間離開等の症状を来たす場合があり， Ivy \& Curtis ${ }^{17)}$ は下颚前歯部の歯間離開を来たした症

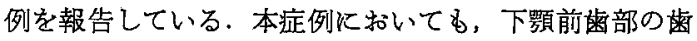

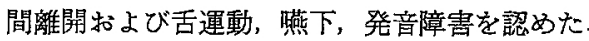

手術方法は, 口内法, 口外法, 両者併用法があり, こ の選択は露胞の位置，大きさによって決定される，口内 法は，無菌的手術という点で不可能であり，口外法は， 顔貌に鯂形を残すが無菌的に手術がでさるといら点で一 長一短か゚ある．本例では，患者の肴望，手術の容易であ ることを考虑し口内法で行った。

予後は一般に良好で，悪性化することはないとされて (る ${ }^{18)}$. しかし, Thoma \& Goldman' ${ }^{6}$ 济に癌性変化 が起り，交献的には1〜6\%で比較的高い頻度でするが， 経験では $0.5 \%$ 程度であったと報じている.土井ら ${ }^{18)}$ 口底類皮粟胞に和いて癌性变化を来たしたるのは未だ報 告が無いようであると述べて扣り，私達が涉猟した範囲 でるみられなかった。

再発については, 完全摘出を行えば再発は起らないよ らである。

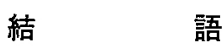

本症例は，27才男性に括ける舌和とがい下型碃胞で，

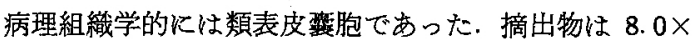
$5.3 \times 5.3 \mathrm{~cm}$ の期円形で, 内容物は軟泥状, 帯黄灰白色 
であった

全麻にてロ䐁内より摘出手術を行い，予後は良好であ った。

本論文の要旨は, 昭和 46 年 9 月, 第19回日本口腔外科 学会九州地方会において発表した。

$$
\text { 文献 }
$$

1) 石川梧朗, 秋吉正豊 : 口腔病理学 (II). 增補版, 永末書店, 京都, 1971 860頁.

2) Meyer, I. : Dermoid cysts (Dermoids) of the floor of the mouth OS. OM. OP $8: 1149$ 1955.

3) Bergmann, E. : Handbuch der praktischen Chirurgie. 4 Auf. Bd 1, Stuttgart, 1913, p. 976.

4) Anderson, W. D. D. : Pathology. Mosby Co, St Louis, 1957, p. 1185.

5) Ackerman, L. V. : Surgical Pathology. Mosby Co, St Louis, 1953, p. 94.

6) Thoma, K.H. and Goldman, H. M. : Oral Pathology, ed 5. Mosby Co, St Louis, 1960, p. 924.

7）高橋庄二郎，大西栄蔵：口腔底皮様茧腫の 2 例な らびに本邦文献による統計的観察. 齿科学報52: 621952.
8) Török : 高橋7)より引用

9) New, G. B. and Erich, J. B. : Dermoid cysts of the head and neck. Surg Gynec \& Obst 65 : 481937.

10）三村房雄：巨大なる口腔底皮梯赛腫症例（付，口 腔底皮様唯腫の統計的観察）大日耳累 $46: 862$ 1940.

11）山下佐英，他：皮様軎胞の11例. 日口外誌 19 ： 4801973.

12）萩崎為行：巨大なる口腔底皮様弯腫の 1 例, 耳喉 $2: 5626551929$.

13）森忠雄：巨大なる口腔底皮椂亯腫の 2 例. 東洋 科月報 $5: 111924$.

14）野村 和, 他：口腔底および頋下部に発生した巨 大類表皮の5腫の 3 症例. 久留米医会誌 $28: 1552$ 1965.

15）新森樹博, 篠原寿宏: 頋下部に発生した巨大な表 皮樣栾胞の 1 例. 日齿評論 $316: 1821969$.

16）長谷川明，他：乳児にみられた大きな口腔底皮様 頳胞の 1 例. 日口外訫 $18: 1871972$.

17) Ivy, R. H. and Curtis, L. : Two cases of sublingual dermoid and a case of protrusion of mandible. Am J Orthodont \& Oral Surg 31 : 6661945.

18）土井尚，他：煩部に発生した類表皮亯胞の 1 例. 日口外誌 $18: 3841972$. 